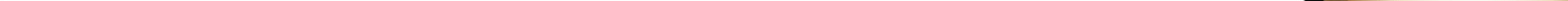




\section{Review of Audio-Vision: Sound on Screen}

\section{Nick Poulakis}

It is evident that during the last 30-35 years there has been a considerable increase of interest considering audiovisual media culture. But, if you had to pick only one book, what would you say is the most significant for establishing the scholarly analysis of the relationship between music and the moving images during the abovementioned period? Indeed, Claudia Gorbman's Unheard Melodies: Narrative Film Music (published at the end of the 1980s) was a breakthrough in the emergent discipline of film musicology; on the other hand, in my opinion, Audio-Vision: Sound on Screen, written by Michel Chion (a composer, filmmaker and professor at the Université de Paris), has been the first book that systematically theorized the field of "film sound/film music studies".

Initially released in French in 1990 as L'Audio-Vision: Son et Image au Cinéma and four years later translated in English by Claudia Gorbman, Chion's renewed, improved and augmented, second edition of this illustrious volume is just exactly what might be expected as an essential textbook in film soundtrack literature. This work summarizes Chion's all-inclusive theory on the "music-image" continuum in cinema. As Walter Murch states in the tome's foreword, "the analysis of sound in films has always been peculiarly elusive and problematical, if it was attempted at all" (p. viii). The theoretical, methodological and epistemological insights of Chion's Audio-Vision 
(along with other relevant academic publications) have come to authorize and further enhance this interdisciplinary domain. Based on the concept of "audiovisual contract", Chion's text moves the discussion away from "synesthesia" (i.e. the impression that the visual and auditory senses are somehow naturally-combined in the human brain).

The opening section of the book is titled "The Audiovisual Contract", a heading that designates the importance of the specific paradigm for Chion's model of analysis. In an endnote, the author reminds us that the "audiovisual contract" (a notion which could be applicable to any audiovisual medium) is "a kind of symbolic contract that the audio-viewer enters into, consenting to think of sound and image as forming a single entity" (p. 249). Other terms introduced by Chion are "added value" and "synchresis". The first one reveals "the expressive and informative value with which a sound enriches a given image" (p. 5) while the second stands for "the spontaneous and irresistible weld produced between a particular sound event and a particular visual event when they occur at the same time" (p. 64). For Chion, these are the most notable relations between sounds and images.

The author devotes an entire chapter to explain and implement Pierre Schaeffer's (1966) scheme of the three (casual, codal and reduced) "modes of listening" in cinema, giving particular examples of film music/sound perception. In another chapter, Chion proceeds to the reformation 
of the classic categorization of "sound-image" encounter that had been developed before by Claudia Gorbman (1987). He proposes two zones (the "acousmatic" and the "visualized") of this interaction where different varieties of sound (onscreen, offscreen and nondiegetic) could potentially be posed in films.

The first part of the volume finishes with a note on the "acousmêtre character" -a type of (cinematically created and acoustically present) voice-character that "involves a specific kind of ambiguity and oscillation” (p. 125), deriving mysterious powers from being heard but not being seen. This neologism corresponds primarily to a disembodied voice of a figure which is "capable of appearing in frame at any time" (p. 202). Chion draws particular attention to this image-sound stipulation because this is a quality of "talking pictures" which is grounded exclusively on the existence of sound.

The second part of the book under the title "Beyond Sounds and Images" begins with Chion's assertion that, even nowadays, cinema maintains "its ontologically visual definition intact" (p. 138), since "a film without sound remains a film; [but] a film with no image [...] is not a film" (p. 139). He continues with a critical account on the several stages of sound technology (such as the multitrack and the Dolby systems) throughout film history that brings cinema closer to the prospect of a global sensorial continuum. 
In chapter 8 , the author emphasizes the extension of his idea of "audio-visual" to "audiologo-visual", highlighting the element of human dialogue in films as presented through numerous either independent or intermixed appearances of theatrical, textual and emanation speech. The last chapter of the book is introductory to the audiovisual analysis of films, defined as the intent to "understand the ways in which a sequence or whole film works in its use of sound combined with its use of images" (p. 172). In this final section, Chion underlines the strengths and pitfalls of examining the aural and optical components of cinema through an assortment of extensive film sequences that illustrate detailed audiovisual analyses. Among others, he offers excerpts from Federico Fellini's La Dolce Vita (1960) and Ingmar Bergman's The Silence (1963). This superb tome ends up with a comprehensive glossary of film music/sound jargon, an annotated chronological list of various landmarks of sound film and a practical index of names and terms.

Chion has been a prolific writer on the topic of sound and music in cinema. This work reveals firsthand that his philosophical, methodological and aesthetic reflections have left a strong imprint on the respective film sound theories in the years that followed its primary publication. Updated and expanded, with additional material from recent film production, the 2019 edition of Audio-Vision will soon take its place as a valuable textbook for those interested in literary research and practice of cinematic soundtrack. 
Dr. Nick Poulakis

Laboratory Teaching Staff

Department of Music Studies

National and Kapodistrian University of Athens

School of Philosophy, University Campus, Zografou, Greece

nick.poulakis@music.uoa.gr

\section{BIBLIOGRAPHY}

Chion, M. (1990). L'Audio-Vision: Son et Image au Cinéma. Paris: Nathan.

Chion, M. (2019). Audio-Vision: Sound on Screen. Second edition. Edited and translated by Claudia Gorbman; Foreword by Walter Murch. New York: Columbia University Press.

Gorbman, C. (1987). Unheard Melodies: Narrative Film Music. Bloomington, IN: Indiana University Press; London: British Film Institute Publishing.

Schaeffer, P. (1966). Traité des Objets Musicaux: Essai Interdisciplines. Paris: Éditions du Seuil. 